1971 Law as Fact, second edition (London, Stevens \& Sons).

Rawls (J.)

1971 A Theory of Justice (Oxford University Press).

$\operatorname{Raz}(\mathrm{J}$.

1979 The Autbority of Law (Oxford, Clarendon Press).

Ross (A.)

1962 "Su Hart", trad. R. Guastini, in Guastini (1980),

pp. $355-360$.

Searle (J.R.)

1969 Speech Acts (Cambridge, Cambridge University Press).

Sextus Empiricus

1948 Les Esquisses Pyrrhoniennes ou Hypotyposes, trad. G. Goron, in OEuvres Choisies de Sextus Empiricus (Paris, Aubier/Montaigne).

Stroud (B.)

1968 "Transcendental Arguments", in The Journal of Pbilosophy, Vol. LXV, no 9, pp. 241-256.

Swift (J.)

1726 Gulliver's Travels, ed. Ch. Lloyd (London, Longman, 1971)

Vernengo (R.)

1964 "About Some Formation Rules for Legal Languages", in Engel (1964).

Winch (P.)

1958 The Idea of a Social Science (London, Routledge \& Kegan Paul).

Wittgenstein (L.)

1953 Philosophische Untersuchungen, ed. G.E.M. Anscombe, G.H. Von Wright \& R. Rhees, in Werkausgabe, Band 1 (Frankfurt, Suhrkamp, 1989).

1967 Ludwig Wittgenstein und der Wiener Kreis, Schriffen, Band 3 (Frankfurt, Suhrkamp, 1980).

\title{
Basic Problems of Harmonizing Tax Law in the European Communities
}

Prof. Dr. Gerhard Laule

Professor, University of Saarbrucken, Member International

Fiscal Association, Board Member of the German IFA-Branch,

International Law Association, Gesellschaft für Finanzwirtschaft in der

Unternehmensführung; International Institute of Public Finance.

TABLE OF CONTENTS

1. Introduction, Review of EEC tax developments; 2. Excise Duties and VAT; 2.1 Excise Duties; 2.2 Value-added Tax; 3. Harmonization of Direct Taxes; 4. Trade Tax and Capital Tax; 4.1 The Trade Tax; 4.2 The Capital Tax; 4.3 Arguments against the discriminating, Trade and Capital Taxes; 5. Income Tax on Individuals; 5.1 Liability to Individual, Income Tax on Trade or Business; 5.2 Tax Scales; 6. Corporate Income Tax; 6.1 The Corporate Income Tax System; 6.2 Liability to Corporation Tax; 6.3 Integrated Companies; 6.4 The Tax Rates; 6.5 Mergers and Acquisitions; 7. Taxable Income; 7.1 Capital Gains; 7.2 Deduction of Losses; 7.3 Trends of the EEC for the Determination of Corporate Income; 8. European Communities Taxation of Corporation; 8.1 Corporation Tax Systems; 8.2 Tax Rates; 8.3 Trends; 9. Summary.

1. Introduction - Review of EEC tax developments

The EEC has recently established principals on a European tax system.

Indirect taxation, VAT as well as excise duties, are subject to political agreements on the harmonization in the EEC after 1992.

Customs have already been uniform since 25 years.

The Commission's new approach on direct tax developments seeks the mutual coordination and approximation of national tax policies by the Member States'.

The Treaty of Rome - the "Treaty" - explicitly deals with indirect taxes, outlawing not only customs duties and export subsidies, which are an obstacle to the free novement of persons, goods, services and capital the four freedoms - within the EEC, but other indirect tax measures, wich would have equivalent effects (Art. 95 to 99 of the Treaty).

The legal basis on harmonization or only coordination of enterprise taxation in the EEC is rather weak. Unlike the indirect taxes - which include in particular the value added tax -, none of the articles provides specifically for a harmonization of direct taxation ${ }^{2}$.
The Commission decided to give priority to measures required to eliminate or reduce obstacles to cross-border activities by 1993, an approach, which accords with the Principle of Subsidiarity; policies should be forged at the most local level which is feasible. The feasibility of implemeting a policy at the local level is closely related to the magnitude of any interjurisdictional spillover effect associated with it ${ }^{3}$.

\section{Excise duties and VAT}

The Coordination of indirect tax systems is provided for by rather precise requirements of the Treaty.

The EEC and the Member States have passed resolutions and agreements on abolishing frontier controls on goods subject to excise duties or VAT.

\subsection{Excise duties}

In September 1990, the EEC Commission introduced proposals on excise duties which are designed to introduce a system of interlinked bonded warehouses and provide a harmonized definition of how excise duties should apply to alcohol, tobacco and mineral oils ${ }^{4}$. 
Germany levies excise duties on many goods. The yield from excise duties is material, when levied on alcohol, tobacco and mineral oils ${ }^{5}$.

Alcohol, tobacco and mineral oils would, as of January 1, 1993, be able to circulate free of duty throughout the EEC.

Duties would only have to be paid in the importing country when the product enters the retail system.

Three Directives provide the technical definitions for each category or structure of goods subject to duties.

The first Directive concerning the structure of excise duties on alcoholic beverages and on alcohol contained in other products, provides for the duty on such products to be calculated per hectolitre of pure alcohol at $20^{\circ} \mathrm{C}$, based on the number of hectolitres of alcohol available to consumers ${ }^{6}$.

The second Directive concerning the structure of excise duties on tobacco provides that duties will reflect the basic retail price, including all taxes and $\mathrm{VAT}^{7}$.

The third Directive concerning the structure of excise duties on mineral oils, stipulates that mineral oils used as fuels are to be subject to excise duties calculated for 1,000 litres at a temperature of $15^{\circ} \mathrm{C}$. However, two types of exemptions are proposed referring to:

- Commercial air and sea transport and

- the production of electricity, farming and in the public transport sector ${ }^{8}$

The Commission has consequently decided against too rigid harmonization of excise duties structures and has, instead, opted for a minimum level of regulation.

The Commission is still considering standard rates of excise duties to be set equal to a minimum rate ${ }^{9}$.

\subsection{Value-added tax}

The value-added tax - VAT - was established through several Directives enacted 1967, which prescribed:

- Taxable persons are all entrepreneurs.

- The taxable base is the consideration for goods supplied, services rendered and the market value of imported goods. 122
- Exports are exempt from tax for reasons of the "destination principle"; the importing Member State levies its VAT on such imported goods so that they carry the same VAT burden as goods from national origin.

- In computing the final tax liability, the "input-tax" for goods and services received from another entrepreneur may be deducted by the entrepreneur, so that only the value added is taxed ${ }^{10}$

Member States importing goods from other Member States controlled such imports at intra-community borders.

After 1992, such fiscal borders have to be removed, based upon different Directives proposed by the EEC Commission and passed through the Council.

The overall impact will be to push down VAT-rates in the EEC as a whole ${ }^{11}$. The VAT-rates differ from country to country. The Commission opted for a minimum level of rgulations; the Commission set a standard rate of VAT equal to or higher than $15 \%$, and the Member States will be authorized to apply reduced VAT-rates equal to or higher than $5 \%$. This regime will become effective as of January 1 , $1993^{12}$

After 1996, the export of goods from one Member State to another Member State wil be taxed following the principle of origin. Such exports will no longer be VAT-exempt. The national VAT of the country of origin may be credited as input tax against the national tax burden of the importing entrepreneur.

Meanwhile, the VAT will be governed by a transitional regime ${ }^{13}$.

- As of January 1, 1993 through December 31,1996 a11 tax checks and formalities at intra-community borders will be abolished. Exports will remain tax exempt, and the payment of VAT will be maintained as at present in the country of destination however.

- In a transaction between persons subject to VAT, the transitional arrangements will take the following form

- the delivery of goods to another community country will be exempt from VAT and
- the purchase of goods in the country of destination will subject to VAT, with the tax being payable by the purchaser.

With regard to non-commercial purchases, the new arrangement will allow complete freedom for individuals to purchase goods in whichever Member State they choose, with such goods being taxed according to the conditions applicable in the state of purchase ${ }^{14}$.

During the transitional period, three special sets of arrangements will apply for the following areas ${ }^{15}$.

- New private vehicles will be taxed in the country of destination, where such vehicles will be registered.

- Mail order business is subject to tax arrangements under the principle of destination of the goods, when the mail ordertrade of a company with another country in the community exceeds 100,000 ECU per year.

- Non-taxable institutions and exempt persons such as banks, insurance companies and public administrations would be permitted to purchases goods in other Member States while paying the rate of VAT applicable in the country of purchase, as long as such purchases do not exceed a certain threshold.

These proposals are backed by another proposal concerning administrative cooperation in the field of indirect taxation such as strengthening exchanges of informa$\operatorname{tion}^{16}$.

\section{Harmonization of direct taxes}

The Treaty requires the removal of all restrictions on the movement of goods and of capital within the community (Art. 67 of the Treaty), on the freedom of establishment of firms (Arts. 52 of the Treaty) and on the approximation of laws which directly and adversely affect

the establishment or functioning of the Common Market (Art. 100 of the Treaty) or

- create distortions in the "conditions of competition" (Art. 101 of the Treaty).
The Treaty furthermore requires the non-discriminatory treatment with regard to the participation in the capital of companies and firms within the meaning of Art. 58 of the Treaty.

In the field of direct taxes on profits, capital, wealth and on income, progress was made during the past two years especially with respect to the problem of international double taxation.

This progress involves three proposals of the EEC:

the Parent/Subsidiary Directive, aimed at eliminating the double taxation of dividends ${ }^{17}$.

- the Arbitration Procedure Convention, designed to eliminate the double taxation resulting from adjustments in transfer-pricing $^{18}$ and

- the Merger's Directive providing for any capital gains arising from a merger or a similar operation to be taxed only upon realization ${ }^{19}$.

Furthermore, in November 1990, the Commission submitted two additional draft directives to the Council:

- The Interest and Royalties Directive, involving the abolition of withholding taxes on such payments within groups of companies within a Member State and across the border ${ }^{20}$. tas.

The Foreign Losses Directive, enabling community enterprises and groups of companies to offset losses incurred as a result of transport activities ${ }^{21}$

Notwithstanding this progress, a number of potential tax obstacles remain to the realization of the full benefits from the completion of a single internal market.

From the German point of view, the national trade tax, capital tax and the taxes on individual and corporate income have to be considered.

\section{Trade tax and capital tax}

The trade tax and capital tax ${ }^{22}$ are a rather constant burden even if profits decrease. They will not be reduced as long as the capital employed in a trade remains cons- 
tant, While earnings are significantly reduced compared with prior years.

4.1 The trade tax

The Federal Republic of Germany levies a direct tax on trade through two instruments:

- the trade tax on income from national sources and

the trade tax on capital employed within Germany.

The tax rate varies considerably from one location to another due to different multipliers applied by the municipalities. On average, the trade tax is between $12 \%$ and $25 \%$ of taxable income for - individual and corporate - income tax purposes.

Trade tax is levied from different sources in Denmark; France, Italy, Luxemburg, Portugal and Spain. Five out of twelve Member States do not levy any trade tax at all, while the German charge on income from business through trade tax is by far the highest within the EEC

4.2 The capital tax

Germany taxes resident corporations and individuals on their worldwide net assets. Non-resident individuals and companies are subject to the capital tax only on certain assets situated in Germany.

The net worth of business assets employed by German corporations is double taxed. The corporation is subject to the capital tax with its assets employed, and the government levies the capital tax on the shares issued by such company at the shareholders level as well.

Luxemburg has established a system similar to the German concept. Greece is taxing capital only if invested in real estate.

Denmark, France, Ireland, The Netherlands and Spain levy a capital tax only from individuals. It is obvious that these countries treat assets of corporations carrying on business with consideration and indulgence. Out of twelve Member States, therefore, three do not levy any capital tax at all, while others charge individuals only, so that capital employed for business purposes is exempt.

124
4.3 Arguments against the discriminating trade and capital taxes

The German trade tax and capital tax on assets employed in business discriminate goods from German origin versus goods from other Member States which levy on profits - taxes only.

The trade tax as well as the capital tax are elements of the cost of capital. They distort decisions on international investment within the Member States. They are reasons of tax distortions on investments in Germany. In addition, both burdens result in costs of goods and services which are unknown in the other Member States.

The national governments levying these taxes discriminate their own economy, which is beyond the control of the $\mathrm{EEC}^{23}$. The commission or the council are only authorized to object measures of a Member State which privilege its citizens or goods from its origin while discriminating citizens or goods from other Member States. Furthermore, there is still doubt whether or not the burden on prices for goods and services is material enough, so that the Commission or the Council should interfere under the Treaty.

The "Report of the Committee of Independent Experts on Company Taxation" published recently, recommends that Member States having such taxes should replace them by an on-profits'-tax levied on the same basis as the central government income tax ${ }^{24}$. This proposal relates to local business taxes, but the reason for the recommendation of this Committee is as well applicable versus the capital tax.

Finally, local income taxes like the German trade tax on income and capital should either be abolished or taken into account when fixing the statutory corporation tax rates.

\section{Income tax on individuals}

Income tax on individuals is a direct charge the harmonization of which is subject to Art. 100 of the Treaty.
Under the conditions of German tax law, the taxation of income is of major importance not only because the tax burden may easily achieve between 65 to $75 \%$ of the annual income, trade tax and capital tax included ${ }^{25}$.

5.1 Liability to individual income tax on trade or business

Residents are liable to income tax on their worldwide income. Non-residents are generally liable to this tax only on certain German source income $e^{26}$.

Revenues from trade or business and other categories of income are integrated into the taxable income. This taxable income is reduced by specially allowed expenditures and exceptional burdens. This results in the amount of income which, after deduction of certain allowances, is subject to taxation in accordance with standard tax rates.

This system applies more or less in al jurisdictions of the Member States on individual income tax.

Partnerships are taxed according to the principle of transparency: profits are taxed in the hands of the partners in proportion to their share in the business, even when they have not actually received the corresponding amount of the profits. This rule applies in nearly all Member States. However, in Belgium, Spain and Portugal, commercial or industrial partnerships are in practice liable for corporation tax; in France, partnerships may opt to pay corporation tax.

The commission nor the council has proposed a scheme yet how to treat partnerships; whether the individual partner should be taxed like a sole proprietor of a trade or business or like a corporation. The option for corporation tax is desirable, and it will depend upon the tax burden under the German income or the German corporate income tax how this option might be exercised.

The determination of the profit from a trade or business in Germany is uniform for an individual, a partnership or a corporation ${ }^{27}$.

5.2 Tax scales

The German individual income tax rates are $19 \%$ for an annual income of 5,617.-
Deutschmarks up to $53 \%$ for an income of 20,042.- Deutschmarks upwards.

The individual income tax rates in other countries than Germany vary, for example, from 25 to $40 \%$ in the United Kingdom, 20\% to $53 \%$ in Spain, $15 \%$ to $40 \%$ in Portugal.

Considering that income from trade or business in Germany is charged with trade tax and capital tax beyond regular income tax, the tax burden easily achieves between $65 \%$ and $70 \%$, which distorts investment descisions and adversely affects the freedom of capital. It is expected that the German charges on income from trade or business will be reduced.

\section{Corporate income tax}

The European Communities have defined a new concept of economic integration in the late 80 's. Priority has now been given to coordination and mutual approximation of Member States' tax systems rather than a systematic harmonization imposed at the EEC level; this also refers to the direct taxes. The advanced concept developed under the Principle of Subsidiarity means that the community as mentioned above can intervene only if the objectives of the Treaty can be better achieved by the community than by the Member States acting separately.

The effort of the European Communities in coordinating tax systems is in principle devoted to the proper functioning of the Common Market and the forthcoming Economic Monetary Union.

To illustrate the Principle of Subsidiariy, the basics of the German corporate income tax system ${ }^{28}$ shall be compared with the corresponding regulations of the other Member States.

6.1 The Corporate Income Tax System

The German corporate income tax system is a total imputation system which completely eliminates the economic double taxation of distributed corporate profits.

Distributed profits are taxed in the hands of an individual resident shareholder and the imputed tax is credited against the recipient's personal tax liability. 
6.2 Liability to corporation tax

The tax is levied on the various types of entities listed in the corporation tax law such as stock corporations and limited liability companies. A taxable person will be charged on worldwide income when it has its legal seat or place of central management within the country. This concept is applied through all the other Member States independently from requirements of the European Communities.

The tax concept for partnerships and for limited liability companies differs from Member State to Member State. The "Ruding Report" recommends the establishment of rules which would permit unincorporated enterprises the option of being taxed as if they were companies ${ }^{29}$, and small companies to be determined by statute shall be permitted to the option of being taxed under the individual income tax law of the Member State where such small corporation has its central place of management.

6.3 Integrated companies

A German group of companies may under certain conditions - be treated for tax purposes as if the companies formed one single unit; their profits and losses are pooled in the hands of the controlling company.

Therefore, lossies of each company can be set off against profits realized within the group.

To qualify for group taxation specific conditions must be met, such as a more than $50 \%$ holding in the daughter company.

Cross border grouping is not permitted.

Within the Member States, the approach to taxation of groups is based on the legal structure of the businesses involved without regard to the economic ties between them.

Several Member States apply a system for tax consolidation - even on a worldwide basis like Denmark, France or Spain - whereby all parts of the group are taxed as a single unit.

There are other varations which achieve some of the effects of consolidation, such as the transfer of losses between the members of the group. In most cases, the bene126 fits of these arrangements depend on the parent having a substantial holding in the subsidiary company and/or upon authorization by the tax authorities. The system is optional.

The sheme for a consolidated tax balance sheet of integrated companies should be extended to all taxes applied in the Member States.

Denmark, France, The Netherlands and Spain have specific provisions with respect to foreign subsidiaries through the consolidation of subsidiaries for tax purposes on a worldwide basis.

The Netherlands have specific provisions with respect to the consolidation of subsidiaries for tax purposes setting up losses of ne company against profits of another company on a worldwide basis.

\subsection{The tax rate}

The German corporate tax rate is $50 \%$ computed on retained earnings; in addition, the solidarity surcharge is due. The refund equals $14 / 50$ of the net distribution.

The current corporate income tax rates show a broad variety of rates on corporate income applied through the Member Sta$\operatorname{tes}^{30}$. The regular rate in Belgium is $39 \%$, in Denmark $38 \%$, in France $34 \%$, in Greece $46 \%$, in Italy $36 \%$, in Luxemburg $33,3 \%$, in the Netherlands $35 \%$, in Portugal $36 \%$, in Spain 35\% and in The United Kingdom $33 \%$. Keeping in mind, that the burden on corporate income in Germany has to take into account the tax on trade and on capital beyond the corporate income tax, only 30

to $35 \%$ may remain as earnings after taxes.

When the German company distributes profits, irrespective of whether the distributions are made out of current profits or out of reserves, part of the corporate income tax is refunded. The effective rate on any profit distribution is $36 \%$. Where the tax rate is $50 \%$ on undistributed profits, the refund equals $14 / 50$ of the net distribution.

6.5 Mergers and acquisitions

In Germany, mergers and acquisitions may be undertaken under favourable fiscal arrangements between companies, partner- ships and a business carried on by sole proprietorship. However, each of the persons involved has to have its place of registration, its seat of central management or its residence within Germany; the law provides for the deferral of taxation on capital gains within the country. Such schemes are applicable in most of the other Member States; however, only for transactions within the domestic jurisdiction. The EEC is challenged to establish tax incentives for mergers and acquisitions across the border of the Member States.

The EEC-proposal on mergers and reorganization of companies provides for deferral of taxation on capital gains on defined cross-border mergers or reorganizations within the $\mathrm{EEC}^{31}$. The exchange of shares together with a related cash payment not exceeding $10 \%$ of the nominal value of the shares will be tax privileged, even if across the border.

Assets transferred across the border and contributed in kind to another company in exchange for shares may be computed on the basis of existing book values not realizing hidden reserves; the same applies to mergers and to the division of companies in which one or more companies being dissolved without going into liquidation, to the transfer of assets and liabilities to another existing or new company, in a exchange of shares issued.

\section{Taxable income}

The tax base for the individual income tax and for the corporate income tax is identical; the corporate tax law refers to the rules on tax accounting implemented in the individual income tax law ${ }^{32}$

The income is the difference between the net worth of the enterprise at the end of the business year and that of the end of the last preceeding business year or, in other terms, income is the total amount of income after deduction of business expenses.

The income tax law includes a sophisticated system of how to evaluate assets, stock etc. $^{33}$, which is applicable for the corpora- tion $\operatorname{tax}$ as well. Business assets may be valued at their cost of acquisition or manufacture or at a going-concern value.

Stock may be valued at its cost of acquisition or manufacture as well or at the going concern value, whichever is lower.

The standard systems of depreciation are the straight line method or the declining balance method. The depreciable base of a business asset acquired for consideration or produced for the business, is its $\operatorname{cost}^{34}$

For certain liabilities or anticipated losses provisions may be set up, thereby reducing taxable income in the year of creation. Such provisions may not exceed the going concern value of the liability and the reflected provision in the commercial balance sheet $^{35}$.

Business expenses are deductible when the business is the cause for such an expense.

Differences in the rules of the Member States to determine the level of taxable profits create distortions which are incompatible with the efficient operation of the internal market ${ }^{36}$

7.1 Capital gains

Capital gains deriving during the course of a trade or a business are treated as ordinary business income. Capital gains, however, on the alienation of certain assets which are replaced by assets of a similar kind be rolled over. Capital losses can be deducted as ordinary income.

For capital gains, the income tax rates of individuals will be reduced by up to one half with respect to income defined as extraordinary income, applicable for an amount not in excess of 30 million Deutschmark. Extraordinary income includes, among others,

- capital gains realized from the sale of a business,

- capital gains realized from the sale of more than $1 \%$ of the shares in a corporation in which the shareholder owns directly or indirectly a substancial intereset which is more than $25 \%$ of the share capital

With regard do financial assets, the "Ruding Report" proposes a directive to the 
effect that upon reinvestment within a fixed period of time, either in fixed assets or in another controlling shareholding capital gains realized on the disposal of a controlling shareholding should not be taxed but there would be a roll over in the tax base of the old assets into the new assets. In the absence of reinvestment, capital gain should be taxed, a correction however for inflation should apply to capital gains realized on fixed assets, in controlling shareholders as well as to all financial investments tha do not constitute cash deposits or other short term monetary assets ${ }^{37}$.

These proposals are sound incentives for investments in business and employment.

7.2 Deduction of losses

In Germany losses accrued can be com pensated in the form of a carry-back and/or a carry-forward. Losses must be copensated first by carrying them back. The carried back losses are deductible up to 10 million Deustschmark. For further losses an unlimited carry-forward has been introduced by $1990^{38}$

Tax losses are treated equally for German individual as well as corporate income tax. All Member States accept carry-forward in principle, subject to various conditions; these conditions result in unequal treatmen on the take-over or reorganization of business. It is the common understanding to harmonize the carry-forward conditions in all Member States.

With regard to losses carried back, there is much less unanimity among the Member States. The existing differences may lead to significant unequal treatment in very specific cases such as mergers and acquisition of businesses.

7.3 Trends of the EEC for the determination of corporate income

Differences in the rules of the Member States to determine the level of taxable profits create distortions which are incompatible with the efficient operation of the internal market ${ }^{39}$.

The Commission had issued a preliminary draft directive on harmonizing the rules 128 for the determination of the corporate taxable base in June 1988; however, the Commission subsequently withdrew the draft directive in May 1989. The Report of the Committee of Independent Experts on Company Taxation came forward with recommendations for further EEC action regarding the taxable base ${ }^{40}$.

The commercial accounts produced for financial reporting purposes should be the start for the computation of taxable income in all Member States. The financial statements and evaluation system of the three Accounting Directives should apply. The balance sheets drawn up in accordance with the Rules for Financial Reporting Purposes thus should determine the items for book entry purposes and form the basis for evaluating assets, liabilities and the taxable profit. Through the standard and internationally accepted accounting principles in all of the Member States, taxable profits should be defined in determing revenues as well as expenses such as depreciation, reserves, provisions or headquarters costs, etc. Divergencies should only take place insofar as the tax law explicitly provides.

\section{European communities taxation of} corporation

The principal differences in the taxation of a business income between Member States relate to the nature of the corporation tax system and statutory tax rates.

8.1 Corporation tax systems

Luxemburg and The Netherlands operate classical corporation tax systems, under which profits distributed in the form of dividends are fully taxed twice, once at the corporate level and again at the shareholders' level. The other $10 \mathrm{Member}$ States provide varying degrees of relief of such double taxation. Imputation credits are granted in Germany, France, Italy, Ireland and the United Kingdom, with France, Germany and Italy providing a full credit for corporation taxes actually paid, while Belgium, Denmark and Portugal levy reduced personal tax rates on dividend receipts.
The different corporation tax systems constitute a source of discrimination against cross-border investment flows.

For this reason, the European Communities were likely to recommend the harmonization of system of company taxation, withholding taxes on dividends through the centralized harmonization of tax systems in the community; half of the corporate income tax dividends distributed should be credited on the level of the recipient. This proposal was withdrawn by the Commission in 1990 applying the Principle of Subsidiarity.

The "Ruding Report" recommends insofar that the Commission and the Member States determine the most appropriate common corporation tax system for the community avoiding discrimination against cross-border investment flows ${ }^{41}$.

The existing discrimination of dividend distributed from profits earned in another Member State shall be removed.

Member States which apply imputation taxes on the distribution of profits earned in another state, should be obliged on reciprocal basis to allow such tax to be reduced by corporate income tax paid in the other Member State in respect of dividends remitted by a subsidiary or profits earned by a permanent establishment. Member States with various forms of tax relief for dividends received by domestic shareholders from domestic companies should be obliged on reciprocal basis to provide equivalent relief of dividends received by domestic shareholders directly from companies in other Member States.

These proposals if accepted would let imputation system be applicable across the border and not only within a national tax jurisdiction.

\subsection{Tax rates}

Furthermore, it is desirable to establish a minimum degree of harmonization with respect to the statutory tax rate.

Following the EEC approach with the VAT, minimum rates should be set at a level that provides Member States with the free- dom to achieve the greatest possible degree of domestic tax neutrality without affecting their existing tax revenues.

Such minimum statutory comporation ax rate could be $30 \%$ in all Member States for all companies ${ }^{42}$.

The maximum statutory corporate tax rate should be $40 \%$ taking in to account that already today most of the Member States levy $40 \%$ or even less corporate income tax Comparing the highest tax rate on individual income tax and today's corporate income tax, the German tax system is neutral versus the legal form of how to carry on business; individual income tax and corporate income tax on retained earnings are very near together ${ }^{43}$. Within a system, where the corporate income tax is only $40 \%$ or even lower, the span between the highest tax rate on individual income and the tax rate on corporate income is increasing; German businesses today run by sole proprietorships or by a partnership will likely be transformed into a corporation.

\subsection{Trends}

The Parent/Subsidiary Directive aims at reducing the differences between taxation rules for nationally organized groups of companies and taxation rules for EC-wide groups ${ }^{44}$. The Member State of the parent company

- either refrains from taxing the profits of a subsidiary that is resident in another Member State

- or authorizes the parent company to deduct from the amount of tax due the corporation tax paid by the subsidiary in the other Member State.

Profit distributions by the subsidiary to the parent company across the border shall be exempt from withholding tax which, for a transitional period, will only be permitted for Germany, Greece and Portugal. The common system of taxation applicable to parent companies and their subsidiaries in different Member States requires a share in the daughter company of at least $25 \%$.

The Convention on the Elimination of Double Taxation - the Arbitration Proce- 
dure ${ }^{45}$ - provides for a cooperation and arbitration procedure to be utilized when Member States cannot themselves reach agreement as to the acquitable elimination of double taxation arising from an adjustment of profits between companies in two or more Member States.

If the tax authorities fail to reach an agreement which eleminates double taxation, the case must be presented to a specially formed arbitration commission, the decision of which is binding. Such arbitration commissions will consist of representatives of the respective tax authorities and a number of independent experts. The tax payer takes part in the procedure and can present his views on the case. This procedure is improving the mechanisms existing under the double taxation agreements ${ }^{46}$.

The EC Commission has submitted a draft directive on a common system of taxation applicable to interest and royalty payments made between parent companies and subsidiaries in different Member States ${ }^{47}$. Withholding taxes on such payments should be abolished. The ability to generate tax free royalty streams may warrant a new look at maximizing licensing opportunities, perhaps based on new product development, or for the right to use trademarks or tradenames. The company loans or royalty arrangements should prove even more taxefficient than dividend flows arising from capital contributions; interest and royalty payments will be deductible, while dividends will be distributed from net income after corporate income tax.

Another draft directive deals with arrangements for the taking into account by enterprises of the losses or their permanent establishments and subsidiaries situated in other Member States ${ }^{48}$.

Member States often have different rules for handling the profits of foreign permanent establishments compared with wholly domestic business. The problem of loss relief does not usually arise in Member States which exempt profits of a foreign permanent establishment or a foreign daughter company and which do not in principle 130 take into account any losses incurred; if they do so, then they subsequently tax any profits made by the permanent establishment up to the amount previously deducted (Belgium, Germany and The Netherlands).

The Commission's proposal will allow Member States the choice of two methods for relieving the losses of foreign permanent establishments and affiliated companies against domestic profits of enterprises: the credit method or the method of deducting losses and reincorporating subsequent profits. In order to qualify for the regime, the parent company must hold at least $75 \%$ of the shares and a majority in the voting rights of the EEC subsidiaries in question ${ }^{49}$. The Member States, however, would also be allowed to introduce other methods such as consolidation.

These proposals will improve the tax treatment of internationally active groups of companies and will support the creation of an internal common market; profits and losses of foreign subsidiaries or foreign permanen establishments situated in one the Member States shall be treated taxwise as if occured in the jurisdiction the parent is registered and has its place of central management.

\section{Summary}

The EC Commission does no longer strive to harmonize for the sake of harmonization but rather to act where communitywide measures were deemed indispensible. An approach which the Commission also used in tackling the problems of indirect taxation. There is a good chance that the coordination of the national tax systems will create a harmonization at a later stage and promote the development of economic activities, a continuous and balanced expan sion, an increased stability, an accelerated raising of the standard of living and closer relations between the Member States as Art. 2 of the Treaty states.

\section{Notas}

In Germany, these policies of the EEC are related to 728, 500 billion Deutschmarks tax yield levied from
3001,0 billion Deutschmarks Gross National Product GNP - for 1991, Finanzbericht 1993, pp. 217, 225; pulis $57,62,84,94$.

2 On the harmonization of direct taxes reference is made to Gert Sass, Probleme der direkten Steuern in der Pespektive des gemeinsamen Binnenmarktes, Vorträge, Reden und Berichte aus dem Europa-Institut der Universität des Saarlandes, Nr. 147, 1988; and Georg Ress, Überlegungen zur Zulässigkeit und zu den Grenzen europäischer Steuerharmonisierung in: Die Europäische Wirt-schaftsgemeinschaft auf dem Weg zum einheitlichen Binnenmarkt und zur Steuergemeinschaft im Jahr 1992, Vorträge, Reden und Berichte aus dem Europa-Institut der Universität des Saarlandes, Nr. 146, 1988, p. 9 et seq.

3 Scrivener, Harmonization of Tax Law within the Scrivener, Harmonization of Tax Law within the Community, European Taxa Report of the Commitee of Independent Experts

Company Taxation,

${ }^{4}$ Howard M. Liebman/Russell M. Patten, Review of EC Tax Developments, European Taxation 1991, p. 364,369

5 In 1992, the revenues of the government from excise duties shall achieve

on tobacco 20,5 billion Deutschmarks, on alcohol (beer included) 8,4 billion Deutschmarks, and

on mineral oil 56 billion Deutschmarks,

Finanzbericht 1993, p. 216

${ }^{6}$ EC Council Directive (Proposal), Official Journa No. C 322 of December 21, 1990, p. 11

7 EC Council Directive (Proposal), Official Journa No. C 322 of December 21, 1990, p. 16

8 EC Council Directive (Proposal), Official Journal No. C 322 of December 21, 1990, p. 18

9 Scrivener, Harmonization of Tax Law within the Community, European Taxation 1990, pp. 355, 357; Van Thiel, Removal of Indirect Tax Barries to a Single European Market, VAT Monitor 1990, pp. 17, 19; Vanghel, Die Harmonisierung der besonderen VerVanghe, Die Hahmen des EWG-Vertrages, 1990, p. 74 t

10 The yield from VAT is estimated by 197,7 billion Deuch Deutschmarks in Germany for 1992, which is

By virtue of the 1992 Tax Amendment Law, the gernal rate will be increased to $15 \%$ as of January, 1993, 1992 rate will be increased of February 25, 1992 BGB1. 1992,297

11 The rates applied at present are listed in the 1992 International Bureau of Fiscal Documentation, EuroInternational Bureau ection A, No. 3/4 of March 1992. 12 See Frankfurter Allgemeine Zeitung of July 29 1992, p. 13, on the compromise of the Member States on the standard tax rate
Van Thiel, Removal of Indirect Tax Barriers to a Single European Market, VAT Monitor 1990, p. 17, 23

${ }^{13}$ EC Council Directive of December 16, 1991, supplementing the common system of value-added tax Official Journal No. L 376/1 of December 31, 1991, Schwarz, Die umsatzteuerliche Übergangsregelung für den Europischen Binnenmarkt ab 01.01.1993, Institu für Ausländisches und Internationales Finanz- und Stevers internationalen Besteuerung Stert Heft 82 ; Mente Die Un in der Europäischen Gemeinschaft

14 Howard M. Liebman/Russell M. Patten, Review of EC Tax Developments, European Taxation 1991, p. 364,367

15 After December 31, 1992, a transitional regime will apply for four years, Official Journal No. L 376/1,5: Title XVI a Art 28 a to Art 281 of December 31, 1991 16 Howard M. Liebman/Russell M. Patten, Review of EC Tax Developments, European Taxation 1991, 364, 368

17 Ref. EC Council Directive - "Parent-Subsidiary Directive" . Official Journal No. L 225 p. 6 of August 20 1990

18 Convention on the elimination of double taxation in connection with the adjustmnet of Transfers of profits between associated enterprises (the Arbitration Procedure), EC Council Convention No. Ar/463, Official Journal No. 11/225 of August $8,1990, \mathrm{p} .10$

19 Ref. EC "Merger Directive". EC Council Directive No. 90/435, Official Journal No. L 225 of August 20 1990 , p. 6 of July 23, 1990 (90/434 EEC)

20 EC Official Journal, No. C 53 of February 28, 1991 , p. 26

${ }^{1}$ Ref. EC Proposal for a Council Directives as described above, Official Journal No. C 53 of February 28 1991, p. 26 and 30

22 The yield from trade and capital tax is estimated at 51 billion Deutschmarks in Germány for 1992, which is essential for the States and for the municipalities wich richt 1993, p. 217

${ }^{23}$ Art. 7 of the Treaty is therefore not violated through Art. 7 of for general remarks see Grabitz, Kommenthese taxes, for general remarks see Gra

24 "Ruding Report" 1992, p. 219.

25 The yield of the individual income tax shall amount to 294,950 billion Deutschmarks in 1992; individual income tax from profits should contribute 39,5 billion De p. 217

26 Krause/Laule/Mennel/Mössner/Runge/Viegener, Principles of German Tax Law, International Fiscal Association, 1981, p. 15, 55

27 See Section 7 below. 
28 The yield of the German corporate income tax is estimated to be 33,4 billion Deutschmarks in 1992, Finanzbericht 1993, 212

${ }^{29}$ See p. 219

${ }^{30}$ See "Current Corporate Income Tax Rates" showing the broad variety of rates on corporate income applied through the Member States from the European Conmunity's Taxation of Corporations, Supplementary Service to European Taxation, Section A, No. 2, Fe bruary 1992

31 See EC Merger Directive of July 23, 1990, EC Council Directive No. 90/434, Official Journal No. 225 of August 20, 1990, p. 1

32 The determination of the profit proceeds on the basis of the commercial balance sheet. Special balance sheet regulations for various forms of corporations must also be considered for tax purposes. The corporation tax law contains provisions to restrict the deductibility of certain operational expenditures such as the capital tax, the turnover tax relating to goods of the corporation which were privately consumed and payments of any kind to members of a supervisory or

33 Krause/Laule/Mennel/Mössner/Runge/Viegener Principles of German Tax Law, International Fiscal Association 1981, p. 17 to 23

${ }^{34}$ Reference is made to Attachment 4, "Typical depreciation rates on industrial buildings and machinery" from the "Ruding Report", p. 179

35 Reference is made to a review of the main tax deductible provisions from the "Ruding Report", $p$ 247; as to this survey, Germany accepts expenditures to build up such provisions if the event occurs during the business.

36 "Ruding Report", p. 211

37 "Ruding Report" p. 217. As to the international trend, an increasing number of tax systems avoid taxes upon earnings generated through inflation; with respect to capital gains see Attachment 8 of the "Rudin Report" p. 243 and with respect to inventories see Attachment 9 of the "Ruding Report" p. 18

38 The "Ruding Report" contains a table on the carryover of trading losses on p. 242 which is attached to this paper as Attachment 6. As to this schedule, international trends indicate an unlimited carry-forward of losses and a carry-back of losses limited timewise. This coordination of the treatment of losses is likely to be introduced by national legislation.

39 "Ruding Report", p. 211

40 "Ruding Report", p. 211, 212

41 "Ruding Report", p. 209

42 This is the proposal of the "Ruding Report", p. 210 ${ }^{43}$ Reference is made to the "Ruding Report" and there Table 8.8. The table shows the difference between top central-government marginal personal tax rates on earnings and corporate tax rate on retentions.
44 See EC "Parent/Subsidiary" Council Directive No. p/435, Official Journal No. L 225 of August 20, 1990, p. 6

45 EC Council Convention No. 90/463, EC Official Journal No. L 225 of August 8, 1990, p. 10

46 Vogel, On Double Taxation Convention, 1991, Art 25, Note 32: "Only representatives of the authorities f those two states whose taxes are involved may take part in a mutual agreement procedure"; Note 76: "The competent authorities are under no obligation to reach agreement in the course of a mutual agreement procedure".

7 EC Official Journal, No. C 53 of February 28, 1991, p. 26

${ }^{48}$ Proposal for a Council Directive concerning arranements for the taking into account by enterprises of the losses of their permanent establishments and subsidiaries situated in other Member States, Official Journo. C 53 of February 28, 1991, p. 30; Liebmann/Patten, Review of EC Tax Developments, European Taxation 1991, 364, 366

49 This concept was developed on the IFA Congress 1979 at Copenhagen and backed by the resolution. Cf. Laule, General Report on: The effect of losses in one country on the income tax treatment in other countries of an enterprise or of associated enterprises engageg in international activites, Cahiers de Droit Fiscal International, LXIVb 1979, p. 71, 94.

\section{A responsabilidade do transportador aéreo pelo fato do serviço e o Código de Defesa do Consumidor}

Antinomia entre norma do CDC e de leis especiais

\section{Cláudia Lima Marques}

professora da Universidade Federal do Rio Grande do Sul

e Mestre em Direito pela Universidade de

Tübingen, Alemanha

Indenizar pela metade é responsabilizar a vítima pelo resto.

Daniel Pizzaro ${ }^{1}$

\section{Introdução}

A entrada em vigor de uma nova lei de função social traz como conseqüência natural uma modificação profunda no ordenamento jurídico vigente. ${ }^{2}$

O Código de Defesa do Consumidor é uma destas leis de função social, as quais têm o mérito de positivar as novas noções valorativas orientadoras da sociedade, procurando, assim, assegurar a realização dos modernos direitos fundamentais (direito econômicos e sociais) previstos nas Constituições. ${ }^{3}$ Leis típicas do intervencionismo do Estado Social, elas nascem com a difícil e específica função de servir de parâmetro, de nova orientação, de efetivo instrument para alcançar o equilíbrio social que o legislador moderno pretende realizar. ${ }^{4}$

Ninguém duvida da árdua e difícil - para muitos praticamente impossível - tarefa de mudar a realidade através de normas jurídicas. ${ }^{5}$ O legislador, porém, na sua sociológica e política finalidade de transformar a realidade cuida de dotar as leis de função social de uma série de características que, no sistema do Direito, isto é, internamente no ordenamento jurídico de determinado país, as possibilitarão cumprir a sua função.

São leis declaradas de ordem pública, a reconhecer a superioridade da lei em rela- ção à autonomia da vontade do indivíduo. São normas, portanto, inderrogáveis pela ação da vontade do indivíduo, a regular de maneira imperativa e imediata as questões jurídicas que tratam. ${ }^{6}$

A modificação no sistema introduzida por estas novas leis é substancial, conseqüência direta do abrangente campo de aplicação que o legislador costuma conceder a estas leis. Muitas vezes, seu campo de aplicação será coincidente com o campo de aplicação de outras leis especiais, de forma a combater privilégios não mais condizentes com os novos valores que pretende introduzir.

$O$ choque entre as novas leis de função social e as leis anteriores do sistema não pode, portanto, ser evitado, ao contrário, integra a própria finalidade da nova lei, que vem para renovar o sistema e assim transformar a própria realidade social.

A finalidade deste trabalho é, justamente, contribuir ao estudo de um destes conflitos desencadeados pela entrada em vigor no novo Código Consumerista. Trata-se da discussão doutrinária a propósito da aplicação e da compatibilidade das regras sobre a responsabilidade do transportador aéreo previstas na legislação aeronáutica, que limita a responsabilidade $e$, portanto, a inde-

R. Fac. Direito UFRGS, Porto Alegre, 9(1): 133-158, nov. 1993 